\title{
Simulation of Air Pollution from Mobile Source Emissions in the City of Rio de Janeiro
}

\author{
I.C.B. Campos ${ }^{\mathrm{a}}$, A.S. Pimentel ${ }^{\mathrm{a}}$, S.M. Corrê $a^{\mathrm{a}, \mathrm{b}}$, G. Arbilla $^{\mathrm{a}}$ \\ ${ }^{a}$ Departamento de Físico-Química, Instituto de Química, \\ Universidade Federal do Rio de Janeiro, Centro de Tecnologia, Cidade Universitária, \\ Bloco A, Sala 408, 21949-900, Rio de Janeiro - RJ, Brazil \\ ${ }^{\mathrm{b}}$ Engenharia de Produção, Universidade do Estado do Rio de Janeiro,
} Rio de Janeiro - RJ, Brazil

\begin{abstract}
Foi usado um modelo de trajetórias simples e o modelo químico SAPRC, com inclusão da química do etanol e do metil-terc-butil-eter (MTBE), para simular as concentrações de ozônio na Avenida Brasil, uma rua muito movimentada na cidade de Rio de Janeiro (Brasil), onde pode considerar-se que a principal fonte de poluição são os veículos. O máximo calculado para ozônio, 22,4 ppb às 14:57 h, está em bom acordo com os dados experimentais. Foram calculadas as isopletas de ozônio, usando dados meteorológicos e de emissões apropriados para esse local, mostrando que esses níveis de ozônio na cidade de Rio de Janeiro são uma consequiência das altas concentrações de $\mathrm{NO}_{\mathrm{x}}$.
\end{abstract}

A simple trajectory model and the chemical mechanism, including the chemistry of ethanol and methyl-tert-butyl ether (MTBE), were used to simulate ozone concentrations at Avenida Brasil, a busy expressway in the city of Rio de Janeiro where emissions from mobile sources are considered to be the major source of air pollution. The calculated ozone maximum of $22.4 \mathrm{ppb}$ at $14: 57 \mathrm{~h}$ is in good agreement with experimental measurements. Ozone isopleth diagrams were calculated based on the meteorological and emission scenario of that expressway, showing that ozone concentrations in Rio de Janeiro are a consequence of the high levels of $\mathrm{NO}_{\mathrm{x}}$.

Keywords: urban air pollution, vehicle emissions, ozone, trajectory modeling, air quality

\section{Introduction}

The available information regarding air quality in the State of Rio de Janeiro (Brazil) is rather sparse. Due to the extreme concentration of the State's population in the Rio de Janeiro Metropolitan Area (RJMA), the most important environmental problems are urban in nature and concentrated in a total of 17 cities $\left(6500 \mathrm{~km}^{2}\right)$, including Rio de Janeiro District and the cities of Niterói, São Gonçalo, Belford Roxo, Nova Iguaçú, Duque de Caxias, Nilópolis and São João de Meriti. The RJMA represents $14.9 \%$ of the State's area and $80 \%$ of its population $(11,000,000$ inhabitants). Air pollution is caused by emissions from industry and the transport sector as well as burned solid wastes. Excessive particulate matter concentrations are routinely observed in the northern part of the municipality of Rio de Janeiro and the Baixada Fluminense (Belford Roxo, Nova Iguaçú and Duque de Caxias), the so-called Airshed III.
In a recent report ${ }^{1}$ it was estimated that in Rio de Janeiro City, $6 \%$ of vehicles use diesel as fuel, $20 \%$ of vehicles use neat ethanol and $73 \%$ use "gasohol" which is a mixture containing $22 \%$ ethyl-alcohol, as an octane booster, added to gasoline. Similar trends are expected for other cities. The use of hydrated ethanol and gasohol reduces direct $\mathrm{CO}$ and non-methane volatile organic compounds (hereafter, VOCs) emissions and increases $\mathrm{NO}_{\mathrm{x}}$ and aldehyde emissions into the atmosphere.

Monitoring of ground-level ozone $\left(\mathrm{O}_{3}\right)$ is insufficient and virtually no systematic measurements are available. Nevertheless, experimental data obtained, in 1996, in Rio de Janeiro City ${ }^{2}$ showed that in downtown and Avenida Brasil, which are characterized by a high traffic density, the levels of ozone are always lower than $50 \mathrm{ppb}$. Similar trends were observed by Tanner et al. $^{3}$ and De Carvalho ${ }^{4}$. In these places, emissions from mobile sources may be considered

\footnotetext{
* fax 5521 590-4746;

e-mail: graciela@iq.ufrj.br
} 
the major source of air pollution. These concentration values seem rather low for a highly-populated city with climatic and geographical conditions, which are conducive to the formation of ozone. Data on peroxyacetyl nitrate (PAN) which is a unique "signature" of the oxidation of ethanol, are limited to a study of Tanner et al. ${ }^{3}$ which showed values $\leq 5 \mathrm{ppb}$.

Experimental data were obtained for $\mathrm{CO}, \mathrm{NO}, \mathrm{NO}_{2}$, total $\mathrm{NO}_{\mathrm{x}}, \mathrm{O}_{3}, \mathrm{SO}_{2}$, VOCs and particulate matter using standard monitoring techniques ${ }^{2}$. The monitoring campaign was realized in Rio de Janeiro in November 1996. It is not the purpose of this paper to discuss the uncertainties and reality of the experimental data. Certainly, the data is limited having been obtained in only a few locations during a short period. However, this is the only available experimental data for ozone levels in Rio de Janeiro in recent years and the data is consistent with earlier results. Since the main goal of this work is to analyze if the measured oxidant concentration values are compatible with the meteorological and emissions conditions of Rio de Janeiro City, only typical data to construct a "base case" are needed. So, the monitoring campaign results were used, in this work, to select boundary conditions of the simulation which give simulated results compatible with the experimental profiles. Then, using these conditions, the ozone isopleth diagrams were calculated and interpreted.

\section{Mobile Sources Characterization}

Using the available information regarding emission parameters and vehicular flux in Rio de Janeiro, a crude estimation of the emission factors was made. The accurate determination of vehicle emissions in a certain area is a difficult task since total mobile source emissions depend on the tailpipe exhaust, mode of operation of the vehicle, its state of repair, evaporation of fuel from various locations in the fuel tank-engine system and ambient temperature. For the city of Rio de Janeiro, dynamometer testing data for representative groups of vehicles are not available. The City has several tunnels, nevertheless there are no tunnel studies which may provide enough data to deduce emission factors and to assess methods to evaluate total vehicle emissions. Since the determination of such a factor is beyond the scope of this work, the emission factors determined by CETESB for the city of São Paulo, Brazil ${ }^{5}$, were used (Table 1). These factors may be considered rather low

Table 1. Emission factors $\left(\mathrm{g} \mathrm{km}^{-1}\right)$.

\begin{tabular}{lccccc}
\hline Type of vehicle & $\mathrm{CO}$ & $\mathrm{HC}$ & $\mathrm{NO}_{\mathrm{x}}$ & $\mathrm{SO}_{\mathrm{x}}$ & $\mathrm{PM}$ \\
\hline Gasohol & 22.5 & 3.7 & 1.2 & 0.22 & 0.33 \\
Ethanol & 16.6 & 3.8 & 1.2 & - & 0.12 \\
Diesel & 17.8 & 2.9 & 13.0 & 2.72 & 0.93 \\
Taxi & 21.3 & 3.8 & 1.2 & 0.18 & 0.29 \\
Motorcycle & 19.1 & 5.6 & 0.1 & 0.22 & 0.20 \\
\hline
\end{tabular}

and, perhaps, they underestimate the gaseous exhaust of mobile sources since there is not a rigorous control of the fleet quality. However, they give a [VOCs] : $[\mathrm{CO}]:\left[\mathrm{NO}_{\mathrm{x}}\right.$ ] ratio more representative of the fuel used in Rio de Janeiro than the emission factors of other countries.

The total number of vehicles was calculated by the DETRAN (Departamento de Trânsito) ${ }^{1}$ as 2.481 .028 in the State of Rio de Janeiro and as 1.236.150 in Rio de Janeiro Municipality (45.50\% of the total gasohol vehicles, $60.32 \%$ of the total alcohol vehicles and $67.39 \%$ of the total diesel vehicles).

The available information shows that in the State of Rio de Janeiro 1,860,518 $\mathrm{m}^{3}$ year $^{-1}$ of gasohol, 1,342,823 $\mathrm{m}^{3}$ year $^{-1}$ of alcohol and 1,637,412 $\mathrm{m}^{3}$ year $^{-1}$ of diesel ${ }^{6}$ are consumed. Using these data and mean values of driving cycles and engine parameters, an estimation of the total emissions of VOCs, $\mathrm{NO}_{\mathrm{x}}$ and $\mathrm{CO}$ was made (Fig. 1).

The vehicular flux on Avenida Brasil, at the Manguinhos location, was characterized using data provided by CET/RIO (Companhia de Engenharia de Trânsito). The data were obtained during the period 11/28/96 to 12/04/96 (Figs. 2 and 3).

\section{The Model and Experimental Results}

The time profiles were obtained using a simple trajectory model simulation ${ }^{7,8}$ and the SAPRC (Statewide Air Pollution Research Center) chemical model ${ }^{9}$ including the chemistry of ethanol and methyl-tert-butyl ether (MTBE). The initial conditions and meteorological parameters were those of Rio de Janeiro City for a particular day (11/27/96) and were taken from published data ${ }^{1}$. The mixing height was taken as $250 \mathrm{~m}$ for 09:00 $\mathrm{h}$ and $1500 \mathrm{~m}$ for 17:00 h, which are typical values for Rio de Janeiro. The total solar flux was computed as a function of the solar zenith angle by assuming clear sky conditions. No available data exist to correct radiation values for the spatial distribution of clouds.

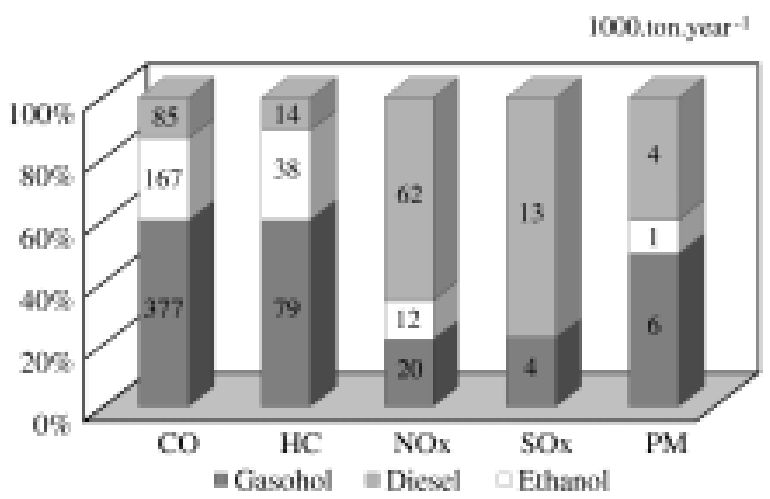

Figure 1. Estimated distribution of vehicular emissions for Rio de Janeiro City in 1997 considering the fuel consumption distribution of Fig. 2 and the emissions factors of Table 1. 
The vehicular flux of Figs. 2 and 3 as well as the calculated emissions factors were used in order to have a crude estimation of mobile source emissions. No attempt was done to include other sources of primary pollutants. Since there are no available data for vehicular flux for that particular day (11/27/96), mean values for the following week were used.

The experimental data for that particular day include total non-methane hydrocarbons, toluene, benzene, ethyl benzene, m-, p- and o-xylene, ozone, $\mathrm{NO}_{2}, \mathrm{NO}, \mathrm{CO}, \mathrm{SO}_{2}$ and particulate matter (PM). Speciation of organic gases is not available for Rio de Janeiro. Previous published results $^{3,10}$ show that in Brazilian cities, ethanol and acetaldehyde concentrations are substantially higher than those measured elsewhere and also acetaldehyde concentrations are often exceeding formaldehyde levels which, in turn, are not very different from those measured in other countries. These data were interpreted as a clear consequence of using ethanol as a vehicle fuel or as a fuel additive. The VOCs distribution (Table 2) was estimated using the above literature data and some recent results for the city of Porto Alegre $(\text { Brazil })^{11}$. Compounds with similar properties were lumped together and their chemistry represented by one or more surrogate species. Ethanol was considered separately

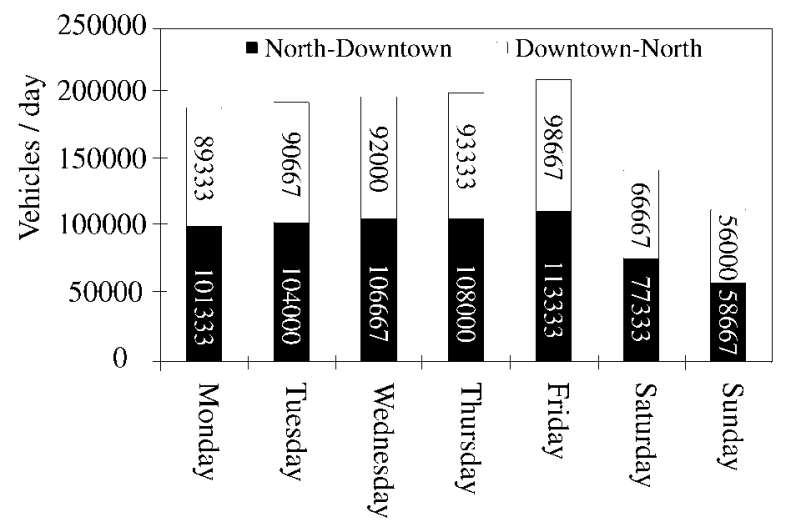

Figure 2. Total vehicular flux on Avenida Brasil in the period 11/28/96 to $12 / 04 / 96$.

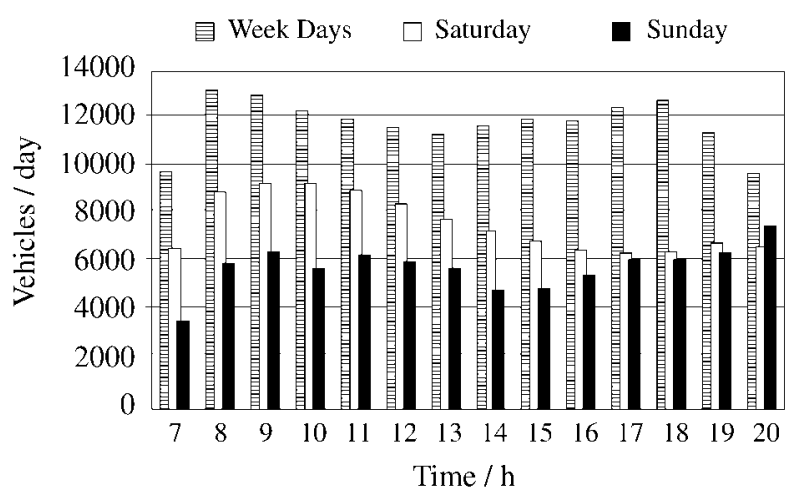

Figure 3. Hourly distribution of vehicular flux on Avenida Brasil in a week.
Table 2. Estimated non-methane hydrocarbon distribution for Rio de Janeiro City in a real and hypothetical scenario (see text for details).

\begin{tabular}{|c|c|c|}
\hline \multirow{2}{*}{ Species or lumped group } & \multicolumn{2}{|c|}{ Relative composition } \\
\hline & $\begin{array}{c}\text { Real } \\
(\text { Gasohol })\end{array}$ & $\begin{array}{l}\text { Hypothetica } \\
\text { (MTBE) }\end{array}$ \\
\hline Alkane $1\left(\mathrm{kOH}_{\mathrm{OH}}<1.010^{-4} \mathrm{ppm}^{-1} \mathrm{~min}^{-1}\right)$ & 0.172 & 0.172 \\
\hline Alkane $2\left(\mathrm{koH}>1.010^{-4} \mathrm{ppm}^{-1} \mathrm{~min}^{-1}\right)$ & 0.112 & 0.112 \\
\hline Alkenes $1(\mathrm{RC}=\mathrm{C})$ & 0.071 & 0.071 \\
\hline Alkenes $2(\mathrm{RC}=\mathrm{CR})$ & 0.064 & 0.064 \\
\hline $\begin{array}{l}\text { Aromatics } 1 \text { (Toluene and ethyl ben- } \\
\text { zenes) }\end{array}$ & 0.128 & 0.128 \\
\hline Aromatics 2 (Xylenes) & 0.053 & 0.053 \\
\hline Formaldehyde & 0.015 & 0.018 \\
\hline Acetaldehyde & 0.031 & 0.018 \\
\hline MTBE & 0.000 & 0.065 \\
\hline Ethanol & 0.066 & 0.040 \\
\hline Methanol & 0.000 & 0.000 \\
\hline Benzene & 0.050 & 0.050 \\
\hline Propane & 0.037 & 0.037 \\
\hline Acetylene & 0.094 & 0.094 \\
\hline Isoprene & 0.004 & 0.004 \\
\hline Ethylene & 0.064 & 0.064 \\
\hline Others & 0.042 & 0.028 \\
\hline
\end{tabular}

from other alkanes. The fractions of Table 2 represent both the initial mixture of VOCs and the emission fractions characteristic of this scenario.

\section{Results and Discussion}

Model results for Avenida Brasil, on November 27, 1996, are presented in Figs. 4-7 for key compounds. These simulated results were obtained using the initial conditions of Table 2. This simple trajectory calculation predicts that ozone should reach a maximum of $22.4 \mathrm{ppb}$ at $14: 57 \mathrm{~h}$ and PAN a maximum of $0.60 \mathrm{ppb}$ at 15:32 h. The value for ozone is in good agreement with the experimental values of $22.5 \mathrm{ppb}$ for 14:00 $\mathrm{h}$ and 22.3 for 15:00 $\mathrm{h}$ as presented in Fig. 7. There are no recent experimental data for PAN concentrations in Rio de Janeiro. In the winter of 1985 values of about $2 \mathrm{ppb}$ were obtained in the period 3-5 July, values $\leq 0.5 \mathrm{ppb}$ for 6-10 July and a peak of $5.4 \mathrm{ppb}$ for the 2nd of July ${ }^{3}$. These data were obtained in Vila Isabel, a location with elevated levels of NO during the peak of the ethanol fuel program in Brazil when a relatively higher number of light-duty vehicles were using pure ethanol as fuel.

The national alcohol program which introduced the use of ethanol produced from sugar cane, was initiated in 1975 


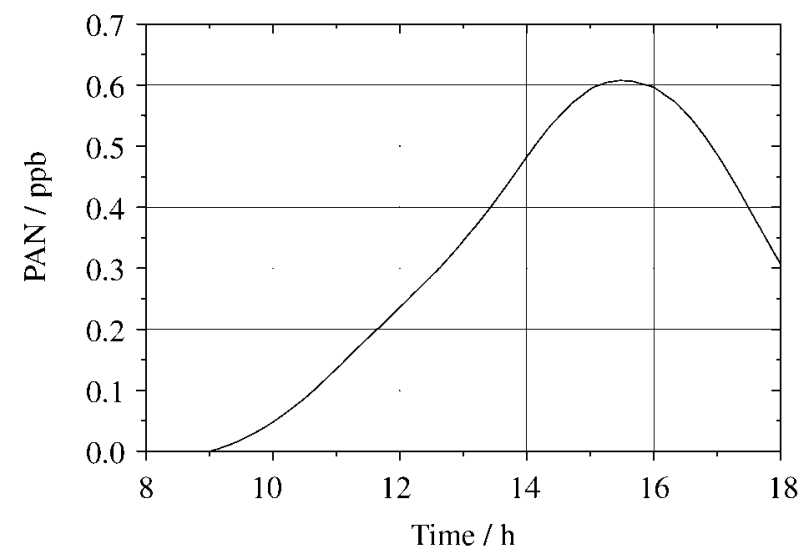

Figure 4. PAN time profiles for a trajectory model simulation of Avenida Brasil on 11/27/96

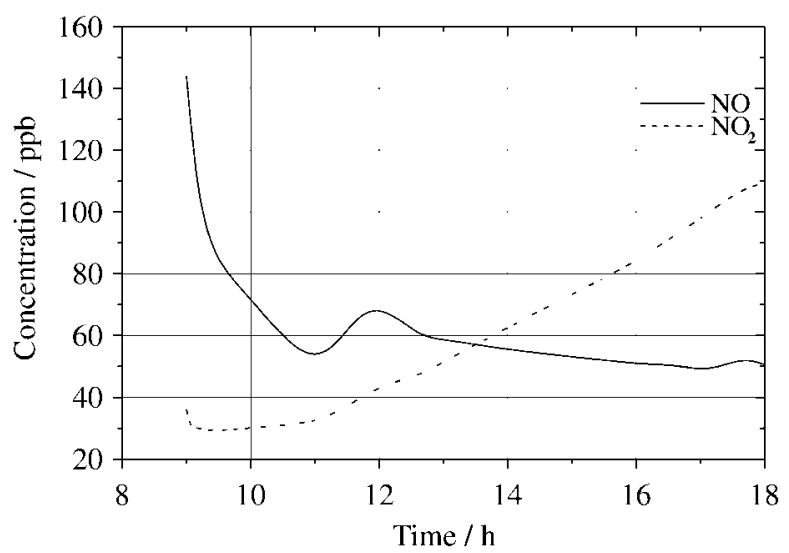

Figure 5. $\mathrm{NO}$ and $\mathrm{NO}_{2}$ time profiles for a trajectory model simulation of Avenida Brasil on 11/27/96.

and changed the country's fuel use and polices and, consequently, the urban air composition ${ }^{12}$. The experimental data of Grosjean et al. ${ }^{10}$ and Tanner et al. ${ }^{3}$ for Salvador, Rio de Janeiro and São Paulo cities, clearly show that the atmospheric levels of acetaldehyde and formaldehyde in Brazilian cities have a close relationship with the vehicular fleet composition and with the large scale use of ethanol as a vehicle fuel, showing low $\mathrm{HCHO}: \mathrm{CH}_{3} \mathrm{CHO}$ ratios and enhanced PAN formation ${ }^{3}$. Also, as previously discussed, the emissions of vehicles using gasohol and ethanol are rather different. Experimental data from CETESB, show that the use of hydrated ethanol and gasohol reduces direct $\mathrm{CO}$ emissions by a factor $\geq 2$ and VOCs emissions by a factor of 1.4 and increases $\mathrm{NO}_{\mathrm{x}}$ by a factor 1.7 .

This situation may be clearly interpreted with the aid of Fig. 8. In this figure, the isopleth diagram for the 11/27/96 scenario is shown. Due to the relatively high concentrations of $\mathrm{NO}_{\mathrm{x}}$ and moderate concentrations of VOCs, the initial concentrations are in the "VOC controlled region". The formation of ozone is limited by the time available for its formation and the relative rate of this process. This rate is strongly influenced by the concentrations of free radical

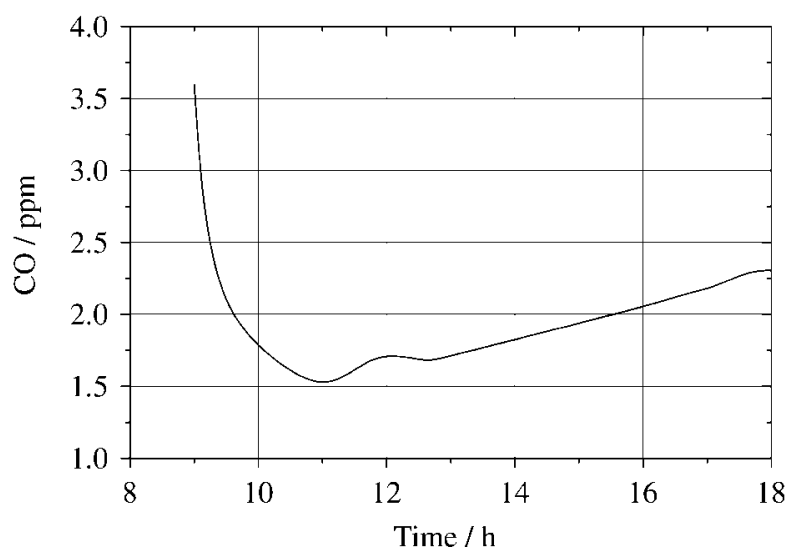

Figure 6. CO time profiles for a trajectory model simulation of Avenida Brasil on 11/27/96.

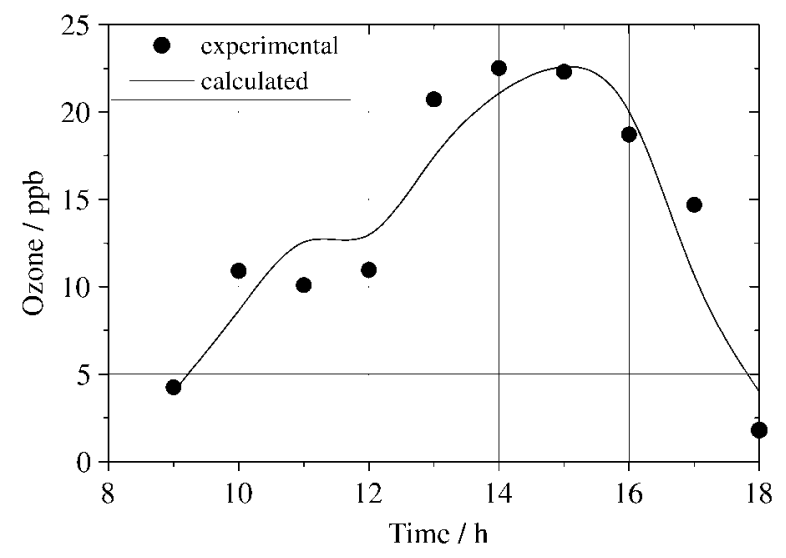

Figure 7. Measured and calculated ozone concentration for Avenida Brasil on 11/27/96.

species involved in the conversion of $\mathrm{NO}$ to $\mathrm{NO}_{2}$, which are sensitive to the VOC concentrations. So, due to the relatively low free radical concentrations the conversion of $\mathrm{NO}$ to $\mathrm{NO}_{2}$ and the formation of ozone are slow giving an ozone peak of $22.4 \mathrm{ppb}$, centered at 14:57. Also, at the high concentrations of $\mathrm{NO}_{\mathrm{x}}$, as the ozone forms, it reacts with the NO present, thus inhibiting the formation of high concentrations of ozone. Data for other streets of Rio de Janeiro, with high rush-hour vehicular traffic emissions of nitric oxide show values as low as $1.0-5.0 \mathrm{ppb}^{2}$. These scenarios were not simulated in the present work because the traffic patterns of these streets are not well characterized. The higher reported value for Rio de Janeiro ozone concentrations is about 50 ppb for January 5, 1988 in Gávea in the Southern region of the City ${ }^{4}$. The results of Figs. 4-8, as well as the other reported values, may be interpreted as a consequence of the high levels of NO which reacts with ozone.

Finally, in Figs. 9 and 10 an hypothetical scenario was tested: with the same meteorological conditions, vehicular flux of Avenida Brasil on 11/27/96, and the VOCs speciation of Table 2, except for ethanol, methyl-tert-butyl ether 


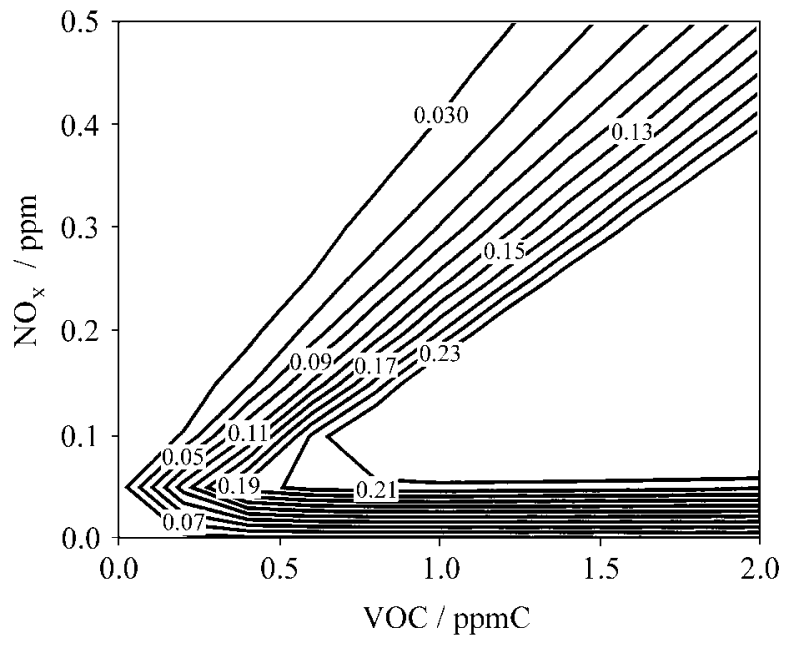

Figure 8. Ozone isopleth diagram for Avenida Brasil on 11/27/96.

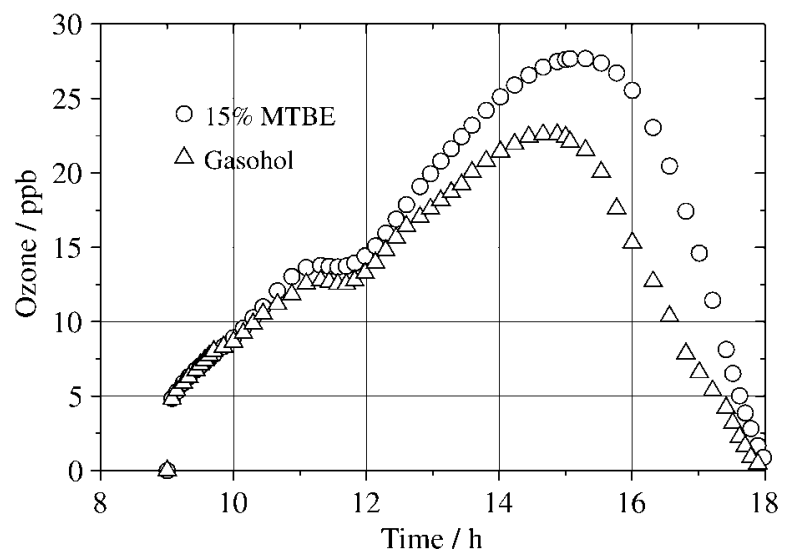

Figure 9. Ozone time profile for gasohol and for an hypothetical scenario using gasoline with $15 \%$ of MTBE.

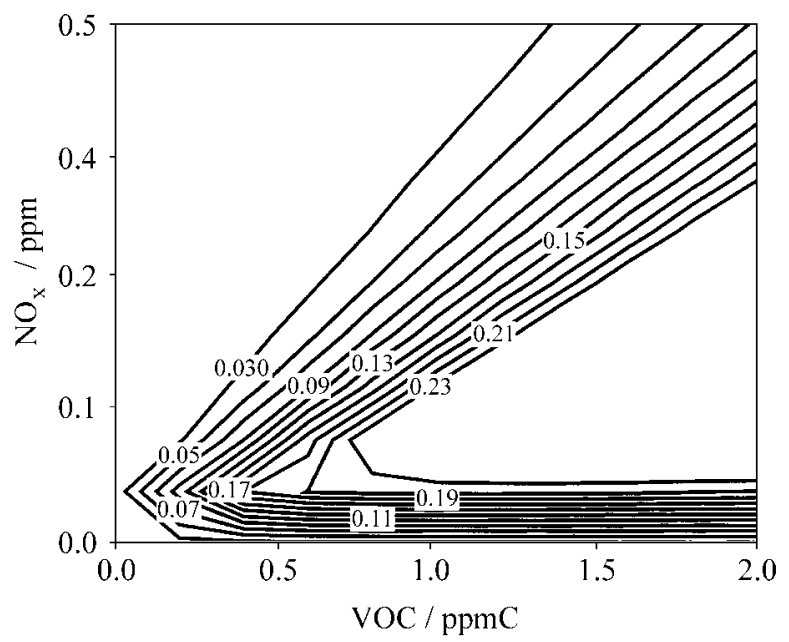

Figure 10. Ozone isopleth diagram for Avenida Brasil on 11/27/96 in the conditions of Fig. 9.

(MTBE), formaldehyde and acetaldehyde. Factor emissions estimated for gasoline with $15 \%$ of MTBE as a fuel
Table 3. Experimental initial and boundary conditions used for the simulation of Avenida Brasil.

\begin{tabular}{lccccccc}
\hline Hour & $\begin{array}{c}\mathrm{T} \\
\left({ }^{\circ} \mathrm{C}\right)\end{array}$ & $\begin{array}{c}\text { R.H. } \\
(\%)\end{array}$ & $\begin{array}{c}\text { I.H. } \\
(\mathrm{m})\end{array}$ & $\begin{array}{c}\mathrm{NO}_{2} \\
\mathrm{ppm}\end{array}$ & $\begin{array}{c}\mathrm{NO} \\
\mathrm{ppm}\end{array}$ & $\begin{array}{c}\mathrm{CO} \\
\mathrm{ppm}\end{array}$ & $\begin{array}{c}\mathrm{VOCs} \\
\mathrm{ppmC}\end{array}$ \\
\hline $9: 00$ & 23.13 & 80.13 & 250 & 0.036 & 0.144 & 3.580 & 0.390 \\
$10: 00$ & 24.04 & 73.71 & & & & & \\
$11: 00$ & 23.44 & 77.42 & & & & & \\
$12: 00$ & 25.20 & 70.16 & & & & & \\
$13: 00$ & 26.70 & 62.96 & & & & & \\
$14: 00$ & 26.05 & 67.91 & & & & & \\
$15: 00$ & 25.84 & 68.68 & & & & & \\
$16: 00$ & 25.46 & 68.46 & & & & & \\
$17: 00$ & 25.22 & 68.24 & 1500 & & & & \\
\hline
\end{tabular}

additive were used ${ }^{13,14}$. A small increment of VOCs emissions is expected (a factor of 1.18 in comparison with gasohol), a reduction of $\mathrm{NO}_{\mathrm{x}}$ emissions (a factor of 0.90) as well as greater $\mathrm{CO}$ emissions (a factor of 1.64). As expected ${ }^{15}$, formaldehyde concentrations are higher (about $10 \%$ ) and ozone concentrations increase, with a maximum of about $27.5 \mathrm{ppb}$.

\section{Conclusions}

Although simple and limited, this simulation is in good agreement with the available experimental data for Rio de Janeiro City. Meteorological, emission and primary pollutant concentrations data for Rio de Janeiro City are, certainly, not enough for implementing a 3D model.

The profile and isopleth diagrams obtained in this simulation corroborate previous experimental evidences that ozone concentrations in urban areas of Rio de Janeiro City are lower than $50 \mathrm{ppb}$. These results may be interpreted as a consequence of the high levels of $\mathrm{NO}_{\mathrm{x}}$, which are characteristic of the fuel policy of Brazil. Also $\mathrm{NO}_{\mathrm{x}}$ and $\mathrm{CO}$ concentrations are lower than the ambient standards.

These simulations ignore the impact of downwind urban and rural areas. The topographic and climatic conditions of the City, with frequent thermal inversions between May and September, suggest that higher concentrations of photochemical oxidants, mainly ozone, may be possible in other regions such us downwind areas. However, there are no ozone and primary pollutant measurements available for these areas and, therefore, it is impossible to conclude with certainty if further vehicle emissions control will be necessary ${ }^{16}$.

Finally, it must be noted that, due to the extensive use of ethanol and gasohol as fuels, Brazil represents a unique scenario for vehicle emissions and further experimental and simulation studies should be implemented. These preliminary simulations show that $\mathrm{O}_{3}$ and $\mathrm{CO}$ levels are lower 
for gasoline with ethanol, while $\mathrm{NO}_{\mathrm{x}}$ levels are higher. The emissions factors for gasoline with MTBE were estimated for the motor regulation and characteristics of Brazil. In these conditions the use of gasoline with MTBE seems to lead to slightly higher concentrations of $\mathrm{O}_{3}$. In this hypothetical scenario $\mathrm{CO}$ concentrations should be higher.

\section{Acknowledgments}

This work was supported by FAPERJ (Rio de Janeiro, Brazil) and CAPES (Brazil). The authors would like to thank Greenpeace (São Paulo, Brasil) for kindly providing the experimental data on air quality, CET/Rio for the traffic data and CENPES/PETROBRAS, REFAP/PETROBRAS and CETESB (São Paulo) for vehicular emission data. They also thank Prof. A. H. Miguel (UC at Riverside, USA) and Prof. J. B. de Andrade (UFBa, Brasil) for copies of their publications.

\section{References}

1. DETRAN. Internal Report on Vehicular Fluxes for Rio de Janeiro City, 1997.

2. Greenpeace Brasil. Contaminação do ar: São Paulo e Rio de Janeiro. Final Report (Volume 2) of the Air Bus (October and November 1996), 1997.

3. Tanner, R.L.; Miguel, A.H.; de Andrade, J.B.; Gaffney, J.S; Streit, G.E.; Environ. Sci. and Technol. 1988, 22,1026.

4. De Carvalho, R.C. Estudo de aldeídos e oxidantes fotoquímicos presentes na atmosfera das cidades de
São Paulo e Rio de Janeiro. Dissertação de Mestrado. Universidade Federal de Minas Gerais, Brasil, 1992.

5. CETESB. Relatório da qualidade do ar no Estado de São Paulo. Final Report, 1995.

6. Geipot. Anuário Estatístico dos Transportes 1996. Empresa Brasileira de Planejamento de Transporte, Ministério dos Transportes, Brasil,1996.

7. Gery, M.W.; Crouse, R.R. User's Guide for Executing OZIPR, U.S. Environmental Protection Agency, Research Triangle Park, N.C., EPA-9D2196NASA, 1990.

8. Finlayson-Pitts, B.J. ; Pitts Jr., J.N. Atmospheric Chemistry: Fundamentals and Experimental Techniques, John Wiley \& Sons, New York, 1986.

9. Carter, W.P.L. Atmospheric Environment 1990, 24 A, 481.

10. Grosjean, D.; Miguel, A.H.; Tavares, M.T. Atmospheric Environment 1990, 24B, 101.

11. Grosjean, E.; Grosjean, D. Environ. Sci. and Technol. 1998, 3205, 2061.

12. Miguel, A.H. Environ. Sci. and Technol. 1991, 25, 590.

13. CENPES, Petrobrás. Private communication, 1997.

14. REFAP, Petrobrás. Estimativa de emissões por fontes móveis para a RMPA. Internal Report, 1997.

15. Bravo, H.A.; Camacho, R.C.; Roy-Ocotla, G.R.; Sosa, R.E.; Torres, R.J. Atmospheric Environment 1991, 25 $B, 285$.

16. Pryor, S.C. Atmospheric Environment 1998, 32, 123. 